\title{
Review of the Literature on Latin America in Ketab-e-Jom'eh
}

\author{
Toloo Riazi* \\ University of California, Santa Barbara, United States
}

Corresponding Author: Toloo Riazi, E-mail: triazi@ucsb.edu

\section{ARTICLE INFO}

\section{Article history}

Received: November 05, 2018

Accepted: December 15, 2018

Published: January 31, 2019

Volume: 7 Issue: 1

\section{Conflicts of interest: None \\ Funding: None}

\author{
Keywords: \\ Iran, \\ Latin America, \\ Revolution, \\ Literature, \\ Weekly Magazine, \\ Leftism, \\ Ideology, \\ Culture
}

\begin{abstract}
This paper aims to analyze a weekly magazine called Ketab-e-Jom 'eh (Friday's Book) and the reflection of Latin American's revolutionary movements in it. Ketab-e-Jom'eh, published from July 26, 1979, to May 22, 1980, was supervised by a number of the most legendary Iranian authors and poets, such as Ahmad Shamloo ${ }^{1}$ and Gholam Hossein Saedi. I focus on the way a particular perspective on Latin American movements is constructed and perpetuated among Ketab-e-Jom'eh's lectors. With a symbolic approach, I analyze those texts through their symbolic representation in the Iranian society, which requires me to study those symbols and their concomitant relevance in Iran. Eventually, I will use an interpretative approach to examine this magazine's ideologically motivated articles in the broader context of the Iranian society with its particular traits. The dialectic relationship between literature and society helps us understand literature as the product of social conditions and influential factors in society. The position that I develop here echoes Louis de Bonald's belief that "through a careful reading of any nation's literature "one could tell what this people had been"” (as cited in Hall, 1979, p. 13). I employ such an expansive horizon to scrutinize the selection of literature on Latin American guerillas. I shall unfold the magazine's ideological orientation from the angle of the context in which it is used. I aim to show that the historical context of the Iranian society at the moment gives those articles specific meanings. In pursuit of my goals, I will recontextualize the articles to determine their primary significance in the Iran of the 1970s and 1980s.
\end{abstract}

\section{REVIEW OF THE LITERATURE ON LATIN AMERICA IN KETAB-E-JOM'EH}

The reception and reflection of the Latin American revolutionary movements, particularly the Cuban guerilla movement, among the Iranian left has been the subject of numerous studies. The aforementioned impact has been analyzed from various angles, among them the style of combat, reception of the Cuban Revolution as a unique experience, and impact of iconic figures such as Che Guevara in making the myth of the Cuban Revolution. Bottici and Challand (2006) talked about "the condensational power of political myth," which can condense itself into "a few images or "icons"” (p. 320). The Cuban Revolution was mostly educed to an icon in its analysis in Iran.

Spinoza stated that society fundamentally consists of historical myths or an "imaginary configuration of desires" (as cited in Hippler, 2011, p. 64). The imagination's function in disclosing the societal order is crucial in Spinoza's thinking. However, "if all societies have an unavoidable imaginative dimension, what they differ in is the degree to which political imagination is subjected to open critical discussion" (Bottici and Challand, 2006, p. 330). Spinoza believed that the historical myth imagination creates a certain degree of knowledge, which is not necessarily the major source of falsity; it is rather the cause of falsity. Nonetheless, this knowledge does not necessarily lead to errors. The error occurs when we forget this knowledge's mythical-imaginary nature or the falsity's truth. (Hippler, 2011, pp. 59-60). What is particular to the Iranian society is the failure of critical thinking on various occasions. By dredging up the writings of the Iranian left, one can see the impacts of books such as Hurricane Over Sugar (1961) and Revolution in Revolution? (1967) in the mythical reception of Latin American guerilla warfare.

In most studies, however, the huge impact of Latin American Revolutions on the Iranian left through the lens of the literature has fallen out of academic fashion. Ketabe-Jom'eh, published from July 26, 1979, to May 22, 1980, was a primary arena for reflecting the ideology of the most important leftist poets and authors, such as Ahmad Shamloo and Gholam Hossein Saedi. These authors and poets enlarged the mythic image of Latin American revolutionary movements. Although very influential, the role of these leftist poets and authors is disregarded. Each magazine has its own policies and way of delivering a particular ideological 
affiliation in its available terms. As Hirsch indicated, a text could sit inside various contexts of interpretations based on various cultural systems. Hirsch distinguished the textual or authorial meanings from the "culture-relative appropriation of a text" (as cited in Graff, 1989, p. 4). That is why the taste of middle-class, leftist, and educated Iranian readers of Ket$a b-e-J o m$ ' $h$ is a crucial element that is taken into consideration. The literature produced by the magazine's editorial board underscores a shared belief in the power of literature as an agent of change and influence. Bearing in mind that words are the embodiment of actions, the so-called committed literature (adabiyat-e mota'ahhed in Persian) provides grounds for the author's actions. Jean Paul Sartre (1988) insisted on the literature's utilitarian essence and considered all acts of writing an action, an act of revealing and committing: "Writing is a certain way of wanting freedom; once you have begun, you are committed, willy-nilly" (p. 69).

Contradicting the idea of "art for the sake of art," Sartre (1988) declared that "the committed writer knows that words are action. He knows that to reveal is to change and one can reveal only by planning to change" (p. 37). He considered writing a form of speaking and hence revealing. The writer writes to change the situation and to reveal it to himself and the reader (Sartre, 1988, p. 38). Actions carry a choice of values (Barone, 1994, p. 95). The actions invigorate social values and tend to permeate the cultural framework. In the Iranian literary tradition, deeming literature "engaged or committed" assigns it a particular ideological orientation and responsibility. The texts on Latin America in Ketab-eJom'eh reflect the concerns and values of the magazine's middle-class, elite readers. Revolution, country, socialism, torture, and dictatorship, the main concerns of Ketab-eJom 'eh's readers, are the recurrent themes in the selection of texts on Latin America. This study endeavors to unfold the reasons for and effects of literary reception of Latin American movements among the Iranian intellectuals in that particular era.

The paper begins by sketching out the relevant reception theories. The reader's role in the construction of meaning is taken up by Griswold (1993) and Alexander (2003), who see a dynamic negotiation between the text and the reader. Reading is not a mere act of reading; it is a synthesis of perception of the words and creation of the meaning (Sartre, 1988, p. 52). Therefore, the texts on Latin America in Ketab$e$-Jom'eh are analyzed from the perspective of the vision of Iranians in the 1970s and 1980s.

\section{LITERATURE REVIEW}

Literature and its role in society has been the subject of several works. It is believed that the first attempt in the sociology of literature was made by Madame de Staël (1800) in France. Gradually, literature became more popular. By and large, the majority of the studies relied on the assumption that literature produces knowledge. Works by Arnold Hauser, Hippolyte Taine, György Lukács, Lucien Goldmann, Karl Mannheim, and Ernest Fischer led to a novel development in the field. For Karl Marx (1952), literature contained the kernel of socioeconomic factors. He evaluated literature based on "the mode of production in material life" (p. 16), and Eagleton suggested that literature is nothing more than a play on ideology (as cited in Hall, 1979, p. 137). Although reviewing the vast ocean of studies can help the reader understand a deep analysis of this theme, such an attempt is beyond the scope of this manuscript. What is crucial in our study are the so called "reception studies" or "influence studies," as François Jost (1974) called them. Reception studies pay particular attention to the fortune, reception, or impact of one country's literature in another country and focus on a two-way relationship between the source culture and the receiving culture. The influence studies engage in a dialogue across time, place, language, and genre (Hardwick, 2003, p.4). In keeping with the reader's importance in influence studies, Steven Mailloux (1998) claimed that "historical context in which judgments are made and supported" (p. 17) and that "political aspects of readers reading" (p. 76) are crucial. Like Jost (1974), I believe that reception studies should be more "concerned with the result or degree of absorption" or "situation of the receiver" (p. 34) rather than "the how of transmission" (p. 34). Reception aesthetics are relevant to the reader's active role in the construction of meaning. As Griswold (1993) suggested, the reader does not come to the text as a blank slate; rather, the text is a platform where the reader's "horizon of expectation" plays an essential role (p. 457). By "horizon of expectation," Victoria Alexander means "nation of origin, race, sexuality, social network, and personal idiosyncrasies" (p.191). Hence, the reader's background exercises a chief influence on the meaning that he or she will attach to the text (Alexander, 2003, p. 191). Based on the approach mentioned above and its fitness for this study, in this paper, I investigate the reasons for and the effects of literary reception of Latin American movements among the intellectuals of Iran with their particular characteristics and under their particular circumstances.

\section{METHODOLOGY}

My concern here is the way a particular perspective on Latin American movements was constructed and perpetuated among Ketab-e-Jom 'eh's readers. Once this argument is established, I will go back to answer this paper's core question: Did this magazine participate in the formation of the Latin American myth in Iran? My analyses will focus on how certain texts published in the magazine mobilized specific symbols and on these symbols' significance in the context of the Iranian culture. I will also examine this magazine's ideologically motivated articles in the broader context of particular traits of the Iranian society. ${ }^{2}$

The dialectical relationship between literature and society helps us understand literature as the product of social conditions as well as literature's influence on the society. The position that I develop here echoes Louis de Bonald's statement that "through a careful reading of any nation's literature "one could tell what this people had been"' (as cited in Hall, 1979, p. 13). I will use this as a starting point for my analysis of the literature on Latin American guerillas published in Ketab-e-Jom'eh. By literature, I mean any kind of text that is published in Ketab-e-Jom'eh. However, I distin- 
guish two categories of "literature" in this regard: the literary works that consist of short stories, poems, and biographies and noncreative works that deal with informative texts.

\section{LITERARY WORKS ON LATIN AMERICA}

The language of the people in charge of Ketab-e-Jom'eh showed a distinctive configuration: a literature sensitive to the country's sociopolitical conditions, which may be called committed literature (adabiyat-e mota'ahhed) ${ }^{3}$. Only with the title can one deduce that a strong politicized tone runs through that group's literary production. In issue 25 , a special edition on Latin America, published in January 1980, the article "Social Commitment and the Latin American Writer" by Mario Vargas Llosa (1978) captured the essence of the so-called committed literature. In the beginning of his article about the suicide of José María Arguedas, Llosa explained that "the Latin American writer finds reasons to become politically conscious and to submit to the pressures of social commitment" (p. 13). He concluded by stating "how difficult and daring it can be to be a writer in Latin America" (p. 13). He believed in the social responsibility of literature, much like the publishers of Ketab-e-Jom'eh. Hauser's (1979) "Propaganda and Ideology in Art" encapsulated what an artist is supposed to do through his or her art:

The artist's position in both [art that contains propaganda and art with a hidden ideological content] is equally partisan and is in furtherance of certain interests, no matter whether this expresses itself through overt propaganda or hidden ideology. The difference is merely tactical... and does not affect the aesthetic stature or the artistic validity and suitability of the means employed. (pp. 129-130)

One can find the traces of such thinking in various places in Ketab-e-Jom'eh. In the fragment by Che Guevara (1989), "New Impulse for Artistic Experimentation," published in a special issue on Latin America, he blamed the artists and intellectuals because they were not real revolutionaries in the creation of their art (p. 47). Ketab-e-Jom'eh's special issue on Chile echoed Galeano (1977), who believed in the word's fundamental role in society:

What is the use of writing if not to defy the blockade which the system places round the dissident message?... Time is short, the challenge crucial and the task enormous: for the Latin American writer committed to the cause of social change, the production of books forms part of a struggle on a multiple front. (p. 20)

No one can deny the fact that the magazine's authors, translators, and the editorial board were not immune from their own ideological orientation in the selection of the texts. Ahmad Shamloo fostered a particular gamut of beliefs, for instance. Generally speaking, as Talattof (2000) suggested, Persian literature is "highly ideological" in its representation (p. 1). Persian literature has gone through major metamorphoses in multiple historical periods. What is common among literary periods, nevertheless, is that they usually have a significant ideological resonance. The figurative expression of equality, heroism, and justice is a key feature of committed literature (Talattof, 2000, p. 67). Even the trans- lation of creative and noncreative works on Latin American revolutionary movements followed the same pattern and vision. Particular works addressing the same topics were selected and published. Regarding the literature as a mirror of their ideology, the magazine's editorial board published a particular selection of texts on Latin America. The Iranian leftist artists, I argue, took refuge in the literature to find the best manifestation for their ideology. My argument is buttressed by examples drawn from multiple issues of Ketab-eJom 'eh. The argument covers some interrelated factors, such as taste, external determinants, and the Zeitgeist.

\section{CONTEXTUAL ANALYSIS OF LITERARY WORKS}

The first issue of the magazine contained an article about Víctor Jara's heroic death, along with a cartoon by the French cartoonist Plantu (Jean Plantureux ${ }^{4}$ ). The short article portrayed the last minutes of Jara's life in the stadium in Santiago, Chile, where he died with honor and dignity. The article, more than anything, emphasized the sacrifice and death for a common cause. In 1979, Ahmad Shamloo introduced Iranian readers to Víctor Jara's songs and manifesto. Later, in a special edition on Chile, the poem "Estadio Chile", or "Somos cinco mil" of Jara, was published. In the same issue, it was announced that a tape full of Chilean revolutionary songs was published by Ebtekar publishing house.

The fourth issue of the magazine, published in August 1979, contained a short story titled "Vivan los compañeros," by the Colombian Carlos Arturo Truque. The short story was customized with a painting and the translation of the story's title into Persian (Figure 1). "Vivan los compañeros" throws a significant light on human relations in the wake of guerilla combat. The 1950s were a period of repression, dictatorship, violence, and censorship in Colombia, particularly during Gustavo Rojas Pinilla's administration. "Vivan los compañeros" was the product of a period when guerilla warfare was crucial in the country.

One can summarize the core of the short story in three levels: guerilla combat, its transformation of humans, and the good days brought about by the guerilla movement. The protagonist struggled with who he was and who he should have been: "Pensé en la lucha tremenda entre esos dos seres, vivientes en un mismo cuerpo, disputándose las risas y las maldiciones; el sin término entre lo que es y lo que debiera ser" (Truque). He knows that, thanks to combat, the good days are coming:

He llorado también, sin darme cuenta; pero al hacerlo, después de tanto tiempo, me he sentido más hombre. He sentido el retorno de algo que creí muerto para siempre. Lo mismo que debió sentir Osorio la noche en que me pidió el abandono de las guerrillas: el regreso a mí mismo, como compensación tardía de esa dualidad del hombre y su camino. Al abandonar la choza, me enfrento, al oriente, con la primera raya blanca, como leche espesa, de la alborada. Entonces corro y abro los ojos a Florito, para que sus pupilas sepan, como lo están sabiendo las mías, que ya empieza el amanecer. (Truque)

"La Horqueta del árbol," by Carlos Garcete (1987), was another symbolic short story that narrated the last heroic 


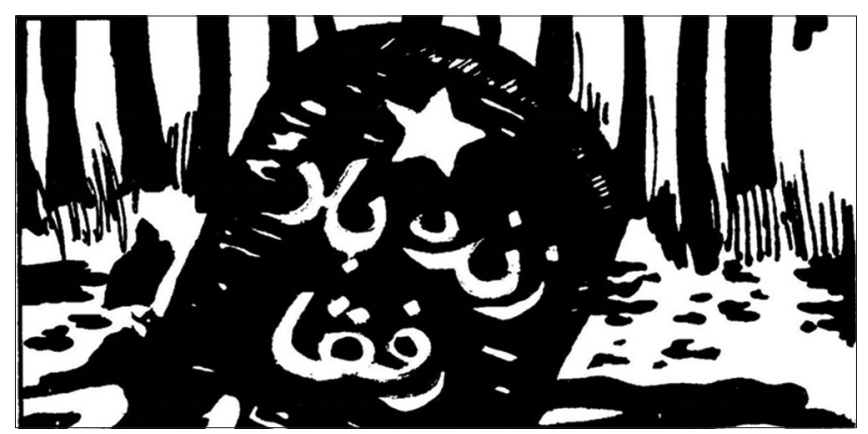

Figure 1. "Vivan los compañeros." August 1979, Ketab-e-Jom'eh, issue (4), p. 80 .

moments of a guerilla named Roberto. Roberto, who was injured, was questioned by officials who were looking for a "guerrillero vivo" to obtain more information about other guerillas and their mission. Roberto tried to give them false information, but he was beaten more, his clothes were taken off, and his tongue and testicles were finally cut off. Víctor, Roberto, and Adolfo were the three revolutionaries who did not have "derecho a caer en flaquezas emocionales" (Garcete, 1987, 20). They had a bigger mission to accomplish. After hours of torture, they accomplished their revolutionary mission: "Cuarenta y cinco minutos después una gran explosión sacudió la tierra” (Garcete, 1987, 21).

Going back to the context of these texts, it is obvious that the magazine sought to support the Iranian movement against the dictatorship with its symbolic reference to similar cases. Issue 27 contained an article memorializing the $10^{\text {th }}$ anniversary of the Siahkal insurgency, known as the Moncada of Iran. The article discussed how the country's beloved children were killed at the hands of Shah's regime and U.S. imperialism. In the same issue, "Patria," a poem by Cuban Roberto Fernández Retamar, was in tune with the eulogy for the martyrs who died for patria (Mam-e-vatan in Persian).

Analyzing various issues of Ketab-e-Jom'eh, I realized that patria (vatan) had been a recurring theme in the selection of poems from Latin America. "Mi Patria," by Honduran Antonio José Rivas, promoted the dominant vision of the magazine's editorial board, depicting a paradigm of revolutionary life and sacrifice for patria. Texts such as Fernández Retamar's "Patria" retain their force by reminding the active reader of his or her own life. This process is called reminder, in which the reader successfully relates the literary content to his or her personal experience (Halász, 1991, p. 79). The reminders could function as simulators of feelings for the reader of Ketab-e-Jom'eh while he or she read them. My point affirms the suggestion by Larsen et al. (1989) that "those readers who have personally lived under similar cultural-historical conditions-culturally close readersare thus expected to be reminded of more concrete events" (p. 98). Now I go back to underpin my study from a threefold perspective: Persian taste, milieu, and Zeitgeist.

\section{THE PERSIAN TASTE, MILIEU, AND ZEITGEIST}

In my analysis of literary works published on Latin America in Ketab-e-Jom'eh, I combine the milieu, Zeitgeist, and taste to conduct my study in this section. Taste, as Schucking observed, is the condensation of man's entire philosophy of life and is responsible for the literature written in his era (as cited in Holub, 1984, p. 50). The seeds of such taste are present in the Iranian people's national characteristics. The Iranian national literature has shown the scars of ongoing invasions, loss, and pain. Years of invasion from without and oppression from within have shaped people's taste in literature. According to literary scholars, that is why satire and comedy never became predominant genres in the country. The imagined community and its respective characteristics, whose significance hardly needs underlining, help shape the people's literary taste. For the same reason, people were more prone and open to the texts focusing on familiar concepts, such as death for the country and the battle against the enemy. The literary texts presented in this section, which painted an enthusiastic and romanticized picture of the Latin American revolutions, were in tune with the Iranian reading public's taste. Myth is an essential element that must be accounted for in the Iranian analysis of Latin America. Indeed, reviewing Ketab-e-Jom'eh offers a unique opportunity to investigate my claim's validity, based on which the Latin American movements acquired a mythical status in Iran. The texts mentioned above helped construct the myth of Latin America in Iran. When reading them, people were fishing in the vast ocean of idealism. I argue that such texts became instrumental in the propagation of the myth of Latin America in Iran, at least among the intellectuals. The mythic framework of patria alongside the ideas that it imparts, for instance, are familiar to the Iranian reader, a reader that was raised with similar concepts. Selflessness and the division of good and evil are part of the Persian culture. The thematic analysis of the aforementioned texts reveals the values to which the Iranian people are acculturated.

The ideological preferences of the magazine's editorial board played a significant role in this regard. The board's way of thinking reverberated throughout the whole magazine. The selected collection on Latin America indicated a pattern of behavior and beliefs to be followed. A text such as "Vivan los compañeros" is displayed as an example. The reader of this text is implicitly asked to conform to this short story's norms and values. It is what Lefevere (2016) called the "shaping power of one culture upon another" (p. 1). This cultural interaction has a lot in common with the concept of transculturality.

The Iranian left arose in response to domestic factors and the particular period in which they lived. Therefore, it seems that the reception of these literary texts on Latin America owed its success partly to the spirit of the period. At the same time, writers such as Maxim Gorky and Jean Paul Sartre enjoyed mythical fame and influence in Iran. The importance of Gorky's and Sartre's literature in the country furnish further evidence for my hypothesis: The Iranian people, under their particular political circumstances, showed more proclivity toward the ideological literature.

The case of Latin America is the same. Indeed, Latin American literature had been enjoying a huge fortune in Iran. Miguel Ángel Asturias's El Señor Presidente came to Iran in 1970, and Torotumbo was published in 1972. Seven Voices; Seven Latin American Writers Talk to Rita Guibert 
(Guibert, 1973) was translated in Iran in 1979. The book is a collection of interviews with seven important and political Latin Americas authors, Pablo Neruda, Jorge Luis Borges, Miguel Ángel Asturias, Octavio Paz, Julio Cortázar, Gabriel García Márquez, and Guillermo Cabrera Infante. Latin American literature's presence and influence do not mean that Iranian guerrilla warfare sprang out of these texts and that many people chose a heroic death after reading them. It is a "shaping approach" based on which the audience assumes a passive role in consuming the culture (Alexander, 2003, p. 182). I do not part company with Alexander with this approach. At the risk of belaboring the point, it is vital to note that the literature on Latin America in Ketab-e-Jom'eh was one of many pieces that shaped the Latin American myth in Iran. The mentioned literary texts might not supply a significant insight into the region and the reception of Latin America by themselves. Nevertheless, this piece of information along with others shaped the myth of those revolutions in Iran. Based on the aforementioned elements, I integrate them and propose the following conclusion regarding the literary texts in Ketab-e-Jom'eh. A question emanates from my argument: Did these texts shape, primarily, the myth of Latin America in Iran, or did that already constructed myth cultivate the reception of texts on Latin America? I believe between these two possibilities interacted with each other. People would like to read such texts more often because they want to know those mythic movements better. By the same token, these texts functioned as a canvas upon which an emotional picture was painted and through which a particular ideology was constructed. The texts also projected the values of Persian culture on that Latin American mythic canvas. That is why "Vivan los compañeros" (Truque) put the "battle of the revolutionaries" on a pedestal and painted it as extremely palatable to the Iranian reader.

The literary works on the Latin American movements in Ketab-e-Jom'eh highlighted the Iranian society's “emotional needs" at the moment "arising out of shared cultural and social life" (Albrecht, 1954, p. 426). The selection of the texts showed that the magazine's sympathies lay with heroic guerillas of Latin America. Consequently, it seems an invitation to the Iranian reader to keep battling.

\section{NONFICTION WORKS}

The second section of this paper aims to investigate how nonpoetic and nonfiction texts portrayed Latin America in Ketab-e-Jom'eh. My analysis in this section shows that those informative texts functioned as a pivotal arena to develop a theory of class struggle, organized labor, and Communism. As indicated in the fourth issue, providing general information on some basic issues was one of the magazine's predominant responsibilities. The editorial board had to find a way to teach people about various issues and at the same time choose or translate texts that addressed the Iranian society's needs. As Shamloo (1979) declared in this issue, the need for change was voiced in the country. However, even the revolutionaries sometimes failed to know the Iranian society. For example, Shamloo talked about revolutionaries who believed revolution could be started in the villages.
He claimed that the lack of information about the society's structure led to a lot of mistakes and even defeats. Ketab-eJom'eh's editorial board called for a more detailed perspective of the society. Therefore, it argued that texts serving a didactic purpose should be an indispensable axis of the magazine. Indeed, Ketab-e-Jom 'eh aimed to redefine the definition and responsibilities of the "intellectuals" in Iran. I found a text by Pablo Neruda titled "Warning to the Intellectuals," in issue 11 , which was in tune with the mindsets of the magazine's editorial board. ${ }^{5}$

Articles such as "Seven Fallacies About Latin America"6 (Stavenhagen, 19687), "The Travail of Latin American Democracy"8 (Therborn, 19799), "In Latin-America They Shoot Filmmakers"10 (Biskind, 1976 ${ }^{11}$ ), and fragments of Dependency and Development in Latin America ${ }^{12}$ (Cardoso, 1979) aimed to provide the reader with more knowledge about the continent and its respective transformations. Informative models were sought not only in Iranian society but also in Latin America's theory and practice. In his introduction to Open Veins of Latin America (Galeano, 1971), ${ }^{13}$ the translator stated that the Third World needed voices that could represent it. Based on the translator, Galeano and his analysis of Latin America can offer the Iranian new viewpoints. The texts by Galeano (1971) and Cardoso (1979), who became the president of Brazil, are classics of Cold War Latin American and dependency theory, which was very influential in the "70s. By the same token, Therborn and Biskind were highly prestigious and influential intellectuals at the moment. The gist of my argument can be clearly proved here. The magazine assigned Latin America a significant weight.

The first article in this category, titled "Argentina: The Land of Continuing Class-Struggle" (my translation), ${ }^{14}$ started with two Latin phrases: "Fabula dua maro lum" and "[D] e $[s i c]$ te fabula narratur." The article embraced the ongoing struggle of people (khalgh in Persian) in its title. A fragment of Revolution and Counter-Revolution in Chile (Raptis, 1974) in the sixth issue, published in September 1979, shed light on the life of the proletariat in Chile. Ketab-e-Jom'eh presented many such texts. Drawing on a text by Camilo Torres (1965), I analyze the general trend of this kind of didactic text in the magazine. In his Platform for a Movement for Popular Unity (1965), the Colombian priest and revolutionary depicts an almost utopian society built on the coalition of all the forces. Although Torres (1965) did not recognize himself as Communist and talked about the brotherhood of human beings, he emphasized the necessity of revolution, agrarian reform, and economic nationalization. Reviewing the noncreative literature on Latin America reveals that Ketab-e-Jom 'eh was home to a number of narratives that were completely in sync with the editorial board's ideological preferences. Those texts highlighted the key theme, argument, and justifications that were being pursued throughout the whole magazine. In other words, the texts on the proletariat and socialism addressed the Iranian intellectual left's concerns, ideals, and goals. These texts on Latin America along with an extensive range of articles on the role of imperialism on Latin America, among them articles by Octavio Ianni and some texts on the Soviet Union, fit into the same category perfectly. 


\section{SPECIAL EDITION ON CHILE}

The special edition on Chile (1979) included various poems by Pablo Neruda; Salvador Allende's last speech; an article by Matilde Urrutia about ${ }^{14}$ Neruda's death; and texts by Beatriz Allende, ${ }^{15}$ Ricardo Garibay, ${ }^{16}$ Yannis Ritsos, ${ }^{1}$ Víctor Jara, Louis Aragon, ${ }^{18}$ and Ralph Miliband. ${ }^{19}$ All the aforementioned texts focused on the sociopolitical changes that engulfed Chile.

The issue focused on Pablo Neruda, Salvador Allende, the Pinochet coup d'état, and the United States' role in it. In analyzing the special issue on Chile, cartoons have to be considered as crucial as the texts. Occasionally, the images spell everything out. A considerable number of cartoons by Brad Holland, ${ }^{20}$ Plantu, and Roland Topor regarding the dictatorship in Chile attracted readers' attention. One may notice that the Shah's and Pinochet's brutality and dictatorship was expressed verbally in the magazine. For Pinochet and the Shah, the military aspect of government was a fundamental element in controlling the country. As a result, countries were ushered into a round of dictatorship, repression, and terror. The images depicted the texts' focal point and asked the reader to see the dictatorship with her or his own eyes and think about it.

The issue's cover page (Figure 2) was a reprint of an illustration by Brad Holland. In a collection called Human Scandals (1977), Holland drew more than 100 illustrations with some significant text alongside the drawings. Holland's drawings were often laden with political meanings. The cover page of special issue of Ketab-e-Jom'eh on Chile is one of Holland's drawings concerning the conflicts in Chile. The original text accompanying this text stated, "Santiago Chile, Oct. 25, 1976 (AP)-Chilean exiles may apply for re-entry to the country if they take an oath not to participate in political activities, the military government announced today" (as cited in Holland, 1977, p. 154). Later in the same magazine, the translation of the text was provided for the reader. Holland's drawings in the magazine surpassed the limited attention they received in the rest of the world and appeared multiple times in Ketab-e-Jom 'eh. Holland's original collection (1977) contained two illustrations concerning Iran and the Shah and two drawings concerning Chile. In a section on Brad Holland's drawings, Ketab-e-Jom'eh reprinted the illustrations concerning Chile and Iran together (Figures 3 and 4)

"Madrid March 1976 (Reuters) Chilean President Augusto Pinochet said here yesterday there are no political prisoners in Chile. Pinochet told a press conference: 'we have no political prisoners. We have "political internal exiles"' (as cited in Holland, 1977, p. 152).

Right after this illustration, another drawing by Holland about Iran appears.

"We don't need to torture people anymore. ...We use the same methods some of the very highly developed nations of the world are (using), psychological methods.' - Mohammad Reza Pahlavi, shah of Iran, quoted in Time, Aug.16, 1976" (as cited in Holland, 1977, p. 150).

\section{TWO SPECIAL EDITIONS ON LATIN AMERICA}

The emotional poem that Che wrote to Fidel Castro was published in a special issue, the $25^{\text {th }}(1980)$. The poem is in tune with the issue's cover (Figure 5). The special issue focused almost exclusively on poems, short stories, and articles related to Latin America. A question lingers here: Out of 34 issues, why were three of them exclusively on a particular geographical location while in other issues, the literature on Latin America was still salient? For instance, Guevara's memories along with his picture appeared in two other issues, the $10^{\text {th }}$ and $15^{\text {th }}$.

The Cuban and Latin American movements have survived ever since, particularly thanks to the myth of exceptionalism. As Antoni Kapcia suggested (2008), for the first time, in his article "Cuba, ¿Excepción Histórica o Vanguardia en la Lucha Anticolonialista?" Che Guevara (1961) called the Cuban revolution an exception. Guevara talked about exceptional elements that led to a successful conclusion (Kapcia, 2008, p. 628). He enumerated the reasons the Cuban revolution became an exceptional success even in Latin America, among them the charismatic figure of Fidel Castro and the country's sociopolitical conditions. This article, along with texts by Sartre and Debray, created a "literature of enthusiasm" (Kapcia, 2008, p. 628) on Cuba. By literature of enthusiasm, Kapcia means a literature that emanates "largely from an embattled US left, keen to herald an already unusual radical phenomenon" (2008, p. 628). Written in the heat of the revolution, this kind of literature generated emotional and enthusiastic evaluations of Guevara, Fidel Castro, and Latin America. The guerrilla insurgency, the triumph over Washington, and skipping the stage theory of traditional Marxism were considered signs of Cuban exceptionalism. The same ideology was extended to Chile's, Nicaragua's, and other movements in Latin America. Whitehead and Hoffman (2016) argued that the Cuban revolution was a perfect case of the David effect, that is to say a model that "from its inception has received more attention, support, administration, and global solidarity than any other state-socialist regime ever, with the possible exception of the Soviet Union" (p. xvi). The myth of exceptionalism applied to the reception of such movements in Iran and consequently animated and emboldened the country's leftist revolutionaries. In this sense, the literature of enthusiasm and admiration of Latin America in three issues of a magazine is not very

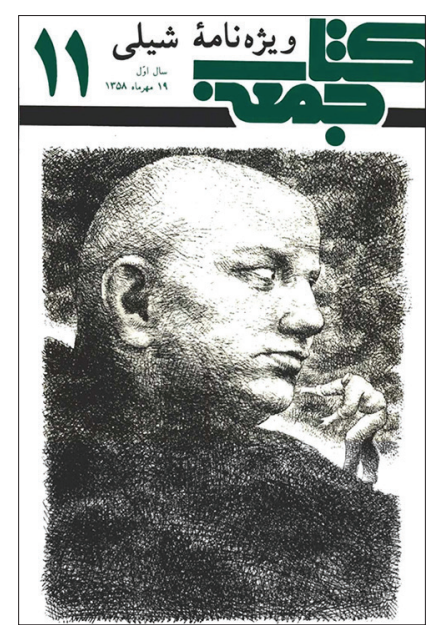

Figure 2. From Human Scandals, by B. Holland, October 1979 , Ketab-e-Jom'eh, issue (11) 


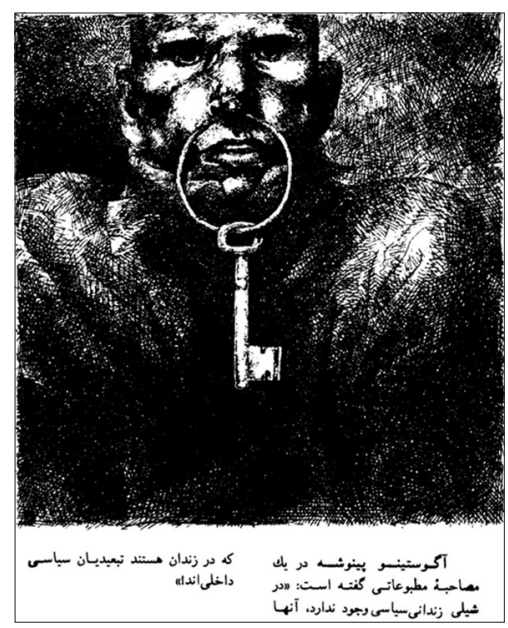

Figure 3. From Human Scandals, by B. Holland, October 1979, Ketab-e-Jom'eh, issue (11)

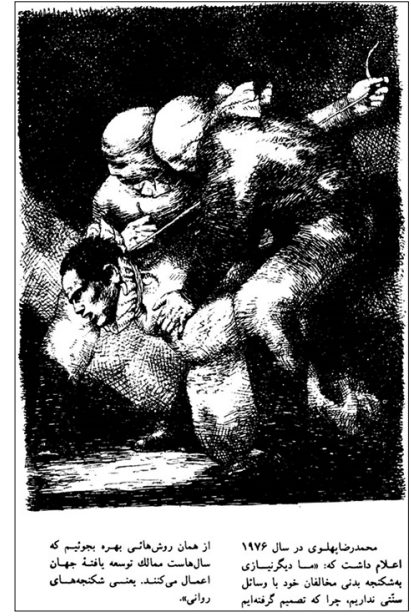

Figure 4. From Human Scandals, by B. Holland, October 1979, Ketab-e-Jom'eh, issue (11)

strange. For example, one of those special issues contained an article by Antonio José Herrera and Hernan Rosenkranz (1979) titled "Political Consciousness in Cuba." Herrera and Rosenkranz undertook a socioeconomic analysis in Cuba in 1976 and provided extensive data in this regard. This article's concluding phrases were highly instructive: "This is the achievement of the seventies: one which contrasts markedly with other Third World countries' experience and would seem to bode well for the future" (Herrera \& Rosenkranz, 1979, p. 68). In the article, Cuban socialism was marked with exception, success, and difference. It was not like other Third World countries. Here, I suggest that the reception of the Latin American movements may have a lot to do with their romantic and idealistic representations in the Iranian literature.

\section{CONCLUSION}

As we discussed earlier, the horizon of expectation is one of the main domains in reception studies. Elements such as nationality, race, sexuality, class, and occupation take part in the construction of meaning for the reader. We know that the

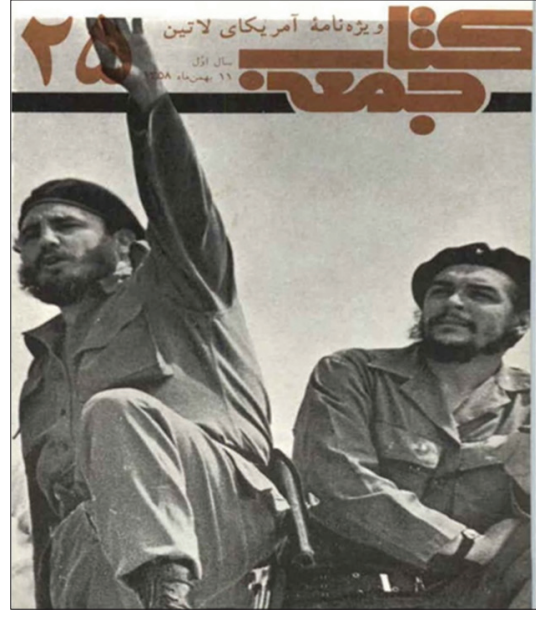

Figure 5. January 1980, Ketab-e-Jom'eh, issue (25)

readers of Ketab-e-Jom'eh were mostly elite, middle-class, leftist, educated people who were experiencing the Iranian Revolution. Griswold (1987) expanded the notion of horizon of expectation and developed her own theory. She proposed ironing out a dialectical interaction between the cultural object and the reader. She suggested that the meaning of a literary text was a fabrication and was derived from the interaction between the work's "potential resources," "symbolic capacities," "presuppositions of human beings," and their "perceptual apparatus" (pp. 1078-1079). She also suggested that the investigator should look at the reception of a literary object from two angles: "socially and culturally constructed percipience of the group" and "the ability of the cultural object to carry multiple messages" (p. 1079). In other words, each category of human beings has a distinctive "period eye" that is constructed by the group's historical experience (Baxandall, 1988).

The texts on Latin America in Ketab-e-Jom'eh addressed some concerns and presuppositions of the readers, who were mostly revolutionaries and leftists. Then the meaning was constructed. The majority of the articles, as aforementioned, orbited around the concepts of revolution, country, socialism, torture, and dictatorship. These themes were encapsulated in the literary text, short stories, poems, and more informative texts. They were similar concerns for the magazine's Iranian readers who engaged in a transnational dialogue with the texts. In analyzing the reception of Latin America in Ketab-e-Jom'eh, it is important to pay special attention to the readers' sociocultural makeup and particular characteristics of the texts published in the magazine. What I have learned in reading and reflecting on literature produced by Ketab-e-Jom'eh's editorial board or even their selection of nonnational literature was imbued with the sense of mission. They valued the so-called committed literature, which had a particular goal.

I have tried throughout this paper to show that the selection of texts on Latin American movements followed a particular ideological pattern. Even the literature on Latin America in the magazine articulated itself in a combative conversation with dictatorship, corruption, and imperialism. Those texts along with books by Sartre and Debray showed 
that the readers' concerns and problems in that particular historical context interacted with those texts to make meaning from them (Griswold, 1987, p. 1112). It has not escaped my attention that the editorial board's and the readers' historical experiences made them more sensitive to the tensions in Latin America.

\section{END NOTES}

1. Also known as the primary translator of Federica Garcia Lorca

2. It is worth mentioning that the textual analysis of this magazine was quite time-consuming. The majority of the texts were provided without any mention of the sources or where they can be found, so I had to locate the texts through a vast investigation via the authors' names. Moreover, the misspelling of some names made this process even more challenging or occasionally impossible.

3. It seems that this kind of literature was influenced by Jean Paul Sartre and his "Littérature engagée" in What Is Literature? For an analysis of Vargas Llosa's article and his political evolution from socialism to the right wing, see Beatriz Valverde Jiménez's article, “The Search for Utopia and its Consequences: Political Commitment in Historia de Mayta by Mario Vargas Llosa and The Honorary Consul by Graham Greene."

4. His works focused mostly on social issues and political satire

5. I could not find this text by Neruda under the aforementioned title.

6. published in Ketab-e-Jom'eh, issue 35

7. Rodolfo Stavenhagen, a Mexican sociologist and anthropologist, was known for his activities regarding the indigenous people's rights. The aforementioned article became very influential and legendary in Latin America. He had a rich corpus of articles on social and cultural developments in Latin America, indigenous people, revolution, and reform

8. published in Ketab-e-Jom'eh, issue 27

9. He is a sociologist and one of the most influential Marxist scholars. He has written extensively on Marxism, post-Marxism, social thought, ideology, and power

10. published in Ketab-e-Jom'eh, issue 27

11. Biskind is a well-known writer, director, and critic. Seeing is Believing: How Hollywood Taught Us to Stop Worrying and Love the Fifties (1983) is one of his most important books.

12. published in Ketab-e-Jom'eh, issue 27

13. published in Ketab-e-Jom'eh, issue 13

14. It was prepared and edited by Kh. Kianoosh.

\section{REFERENCES}

Albrecht, M. C. (1954). The relationship of literature and society exploring fine and popular forms. American Journal of Sociology, 59(5), 425-436.

Alexander, V. D. (2003). Sociology of the arts. Malden, MA: Blackwell Publishing.
Asturias, M. Á. (1971). Torotumbo. Mexico, DF: Universidad Nacional Autónoma de México.

Asturias, M. Á. (2000). El señor presidente. San José, Costa Rica: Editorial Universidad de Costa Rica.

Barone, T. E. (1994). On Kozol and Sartre and educational research as socially committed literature. The Review of Education/Pedagogy/Cultural Studies, 16(1), 93-102.

Baxandall, M. (1988). Painting and experience in fifteenth century Italy: A primer in the social history of pictorial style. New York, NY: Oxford University Press.

Biskind, P (1976). In Latin-America they shoot filmmakers. Sight and Sound, 45(3), 160-161.

Bottici, C., \& Challand, B. (2006). Rethinking political myth: The clash of civilizations as a self-fulfilling prophecy. European Journal of Social Theory, 9(3), 315-336.

Cardoso, F. H. (1979). Dependency and development in Latin America. Berkeley, CA: University of California Press.

Galeano, E. (1971). Open veins of Latin America: Five centuries of the pillage of a continent. New York, NY: Monthly Review Press.

Galeano, E. (1977). In defense of the word. Index on Censorship, 6(4), 15-20.

Garcete, C. (1987). El collar sobre el río. Buenos Aires, Argentina: Editorial Futuro.

Graff, G. (1989). Narrative and the unofficial interpretive culture. In J. Phelan (Ed.), Reading narrative: Form, ethics, ideology (pp. 3-11). Columbus, OH: Ohio State University Press.

Griswold, W. (1987). The fabrication of meaning: Literary interpretation in the United States, Great Britain, and the West Indies. American Journal of Sociology, 92(5), 1077-1117.

Griswold, W. (1993). Recent moves in the sociology of literature. Annual Review of Sociology, 19(1), 455-467.

Guevara, E. (1961). “Cuba: ¿Excepción histórica o vanguardia en la lucha anticolonialista?" Retrieved from http:// www.fidelcastro.cu/es/articulos/cuba-excepcion-historica-o-vanguardia-en-la-lucha-anticolonialista

Guevara, E. (1989). New impulse for artistic experimentation. In Ernesto Guevara (Ed.), Socialism and man in Cuba (pp.35-37). New York, NY: Pathfinder.

Guibert, Rita. (1973). Seven Voices; Seven Latin American writers talk to Rita Guibert. New York, NY: Vintage Books.

Halász, L. (1991). Effect and reminding in literary text processing. In E. Ibsch \& D. Scharm \& G. Steen (Eds.), Empirical studies of literature (pp.79-85). Amsterdam: Rodopi.

Hall, J. A. (1979). The sociology of literature. Harlow, England: Longman Publishing Group.

Hardwick, L. (2003). Reception studies. Cambridge, England: Cambridge University Press.

Hauser, A. (1971). Propaganda, ideology and art. In I. Mészáros (Ed.), Aspects of history and class consciousness (pp. 128-152). London, England: Routledge.

Herrera, A., \& Rosenkranz, H. (1979). Political consciousness in Cuba. In J. Griffiths \& P. Griffiths (Eds.), Cuba: The second decade. London, England: Writers and Readers Pub. Cooperative Society.

Hippler, T. (2011). The politics of imagination: Spinoza and 
the origins of critical theory. In C. Bottici \& B. Challand (Eds.), The politics of imagination (pp. 55-73). New York, NY: Birkbeck law press.

Holland, B. (1977). Human Scandals. New York, NY: Push Pin Press.

Holub, R. C. (1984). Reception theory: A critical introduction. London, England: Methuen.

Jost, F. (1974). Introduction to comparative literature. Manitoba, Canada: Pegasus Publications.

Kapcia, A. (2008). "Does Cuba fit yet or is it still "exceptional”? Journal of Latin American Studies, 40(4), 627-650.

Larsen, S. F., Laszlo, J., \& Seilman, U. (1989). Across time and place: Cultural-historical knowledge and personal experience in appreciation of literature. Empirical studies of literature: Proceedings of the second IGEL-conference, 97-104.

Lefevere, A. (2016). Translation, rewriting, and the manipulation of literary fame. London, England: Routledge.

Llosa, M. V. (1978). Social commitment and the Latin American writer. World Literature Today, 52(1), 6-14.

Mailloux, S. (1998). Reception histories: Rhetoric, pragmatism, and American cultural politics. Ithaca, NY: Cornell University Press.

Marx, K., \& Engels, F. (1952). Literature and art: Selections from their writings. Saint Luis, Missouri: Telos Press.

Raptis, M. (1974). Revolution and counter-revolution in
Chile: A dossier on workers' participation in the revolutionary process. London, England: Allison \& Busby.

Retamar, R.F. "Patria." Retrieved from https://narrativabreve.com/2016/04/cuento-de-carlos-arturo-truque-vivan-los-companeros.html

Rivas, A.J. "Mi patria.” Retrieved from http://honduraspoetica.blogspot.com/2009/09/mi-patria.html

Sartre, J. P. (1988). "What is literature?" and other essays. Cambridge, Massachusetts: Harvard University Press.

Stavenhagen, R. (1968). Seven fallacies about Latin America. In J. Petras \& M. Zeitlin. (Eds.), Latin America: Reform or revolution? A reader (pp. 13-31). New York, Ny, Fawcett Premier.

Talattof, K. (2000). The politics of writing in Iran: A history of modern Persian literature. New York, NY: Syracuse University Press.

Therborn, G. (1979). The travail of Latin American democracy. New Left Review, 71-109.

Torres, C. (1965). Platform for a movement for popular unity. Truque, C. A. "Vivan los compañeros." Retrieved from https://narrativabreve.com/2016/04/cuento-de-carlos-arturo-truque-vivan-los-companeros.html

Whitehead, L., \& Hoffman, B. (2016). Debating Cuban exceptionalism. New York, NY: Springer. 